\title{
TATIANA BLASS
}

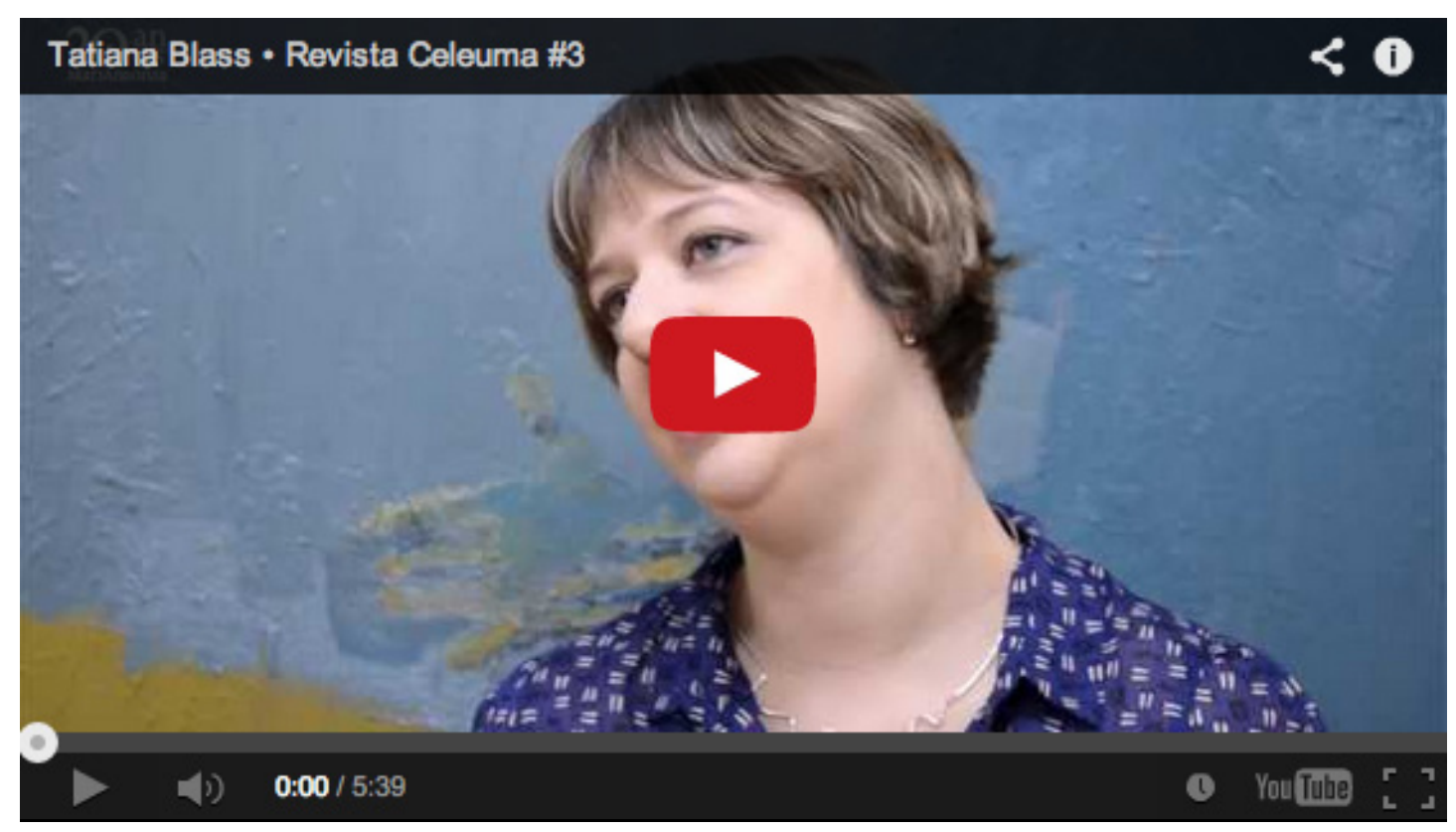

